\title{
PAX6 wt Allele
}

National Cancer Institute

\section{Source}

National Cancer Institute. PAX6 wt Allele. NCI Thesaurus. Code C75889.

Human PAX6 wild-type allele is located in the vicinity of $11 \mathrm{p} 13$ and is approximately $29 \mathrm{~kb}$ in length. This allele, which encodes paired box protein Pax- 6 , plays a role in the mediation of transcription. Mutations in the gene are associated with a number of congenital disorders of the eye. 